\title{
EFFECTIVENESS OF GO GREEN EDUCATION IN EARLY CHILDHOOD IN ECOLOGICAL DISASTER MITIGATION EFFORTS
}

\author{
ASMUNGI \\ Institut Pemerintahan Dalam Negeri \\ Asmungi.ipdn@gmail.com
}

\begin{abstract}
Based on data from various sources, there are currently many natural disasters (ecological disasters) in different regions in Indonesia. Environmental hazards in the form of floods, landslides, volcanic eruptions, forest fires, smog, and so forth. Ecological disasters can occur due to natural factors or due to human intervention. Environmental hazards will get worse if prevention is not done early. One way to mitigate ecological disasters is to instill the character of caring for the environment early on. The question is whether character education cares about the environment? What does this have to do with ecological disaster mitigation efforts? How do you teach character education to care for the environment from an early age? These questions become the common thread in this article. The character of caring for the situation cannot be obtained instantly but requires a long process and a relatively long time. Someone will have a caring attitude towards the environment because of the habituation that takes place continuously and continuously. Habituations that take place consistently will be firmly planted in the subconscious mind so that they will later be exposed to their actions in daily life (habits) as the character values they have. A child who has the character of caring for the environment will have a positive impact on the survival of the surrounding environment. This is where the importance of efforts to prevent (mitigate) ecological disaster early on.
\end{abstract}

Keyword: Environmental Care Character Education, Early Childhood, Ecological Disaster Mitigation

\section{A. INTRODUCTION}

Based on the results of the study of the Indonesian Forum for the Environment (WALHI), it was revealed that the environmental conditions in Indonesia were increasingly threatened, mainly because of infrastructure development. WALHI considers that the ecological disaster (ecological disaster) that has occurred to this day is due to the continued reduction in the area of forest cover, and the increase in the extent of critical lands. WALHI reports that in 2014, there were 817 ecological disasters in various regions in Indonesia. The environmental catastrophe consisted of 608 floods, 191 landslides, and 18 times. The National Disaster Management Agency (BNPB) noted that between January - June 2016, there were 442 floods, 30 floods, and landslides, 261 landslides. Two hundred fourteen people died as a result of the ecological disaster. Despite the decrease in the intensity of flooding from 2014, the incidence of landslides in 2016 has increased. There are still many areas that have experienced ecological disasters, and the resulting fatalities indicate that ecosystems in Indonesia have suffered significant damage. 
Meanwhile, Greenpeace is calling for Indonesia to be free from waste and incinerators. This is reasonable because of Indonesia as the world's second-largest contributor of trash to the oceans (Jambeck et al., 2015: 769). Disposal of waste into the sea will adversely affect the life of the marine ecosystem (Nasution et al., 2016: 1). The sea will be polluted, causing various species of fish to die, coral reefs damaged, and very pessimistic views. Berry added that the use of incinerators to burn trash is also dangerous because it can produce dioxins which can cause cancer in humans.

Environmental quality is reduced due to the exclusion of environmental issues and impacts in development, becoming a significant factor in ecological disasters that affect the social and economic class. A report from the Intergovernmental Panel on Climate Change (IPCC) in 2007, which was launched by the World Wide Fund of Nature (WWF) Indonesia page, states that recent changes in temperature have affected many systems both physical and biological nature. The level of the possible threat of climate change is said to be high confidence at around $80 \%$. Even the IPCC estimates that at the end of the 21st century, the earth's temperature will rise by $1.80 \mathrm{C}$ - 4 OC, while sea levels will rise as high as $28-43 \mathrm{~cm}$ if there is no serious effort to reduce the concentration of greenhouse gases.

The University of Adelaide, in its latest research on the environment, published the results of his study that Indonesia is the fourth largest country that contributes to environmental damage on earth. There are seven indicators used to measure ecological degradation, namely deforestation, the use of chemical fertilizers, water pollution, carbon emissions, fishing, and the threat of plant and animal species, and the conversion of green land into commercial lands such as malls or trade centers, and also plantations (Kristanti, 2010: 1).

Olivia Lewi Pramesti from National Geographic Indonesia reports that environmental portraits in Indonesia are becoming increasingly alarming from year to year. These environmental case trends continue to increase along with regional policies in managing their respective regions. Based on the latest data from the Ministry of Environment (KLH), in 2012, there were already 300 environmental cases such as forest fires, ecological pollution, lawlessness, and mining. Based on the Environmental Quality Index made by the Ministry of Environment, there was a decrease in environmental quality, namely in 2009 amounted to $59.79 \%$, in 2010 amounted to $61.7 \%$, and in 2011 amounted to $60.84 \%$.

Data compiled by Forest Watch Indonesia (FWI) writes that the area of Indonesia's forest cover in 2000 was 103.33 million ha. The city of forest cover in 2009 was reduced to 88.17 million ha or had experienced deforestation of 15.15 million ha. Thus, Indonesia's deforestation rate in this period is 1.51 million ha per year (Sumargo et al., 2011: 15). It is possible that in 2016, the area of forest cover in Indonesia will decrease.

Indonesia's vulnerability to the threat of ecological disaster is increasingly apparent. This vulnerability can be demonstrated by the change in forest areas to non-forests, the conversion of forests and peat swamps for mining and plantations, as well as logging of natural forests for the needs of industrial raw materials, such as the pulp and paper industry. This problem is the root that causes deforestation, outside of illegal logging which causes degradation and decreases the quality and quality of the environment (WALHI, 2015: 13) 
Forest fires and the conversion of peatlands into plantations are among the main factors causing environmental damage. According to Kurnianto (Moss, 2015) researchers from the Center for International Forestry Research (CIFOR) state that Indonesia's peat swamps have evolved over thousands of years to create a perfect storage system to lock in carbon dioxide that contributes to climate change, but unfortunately we only recently realized and understood how much emissions are released when peatlands are cleared and burned for agriculture or oil palm. Utomo (2015: 1) and Moss (2015: 1) stated that many bogs were damaged due to land conversion to oil palm plantations. Of the 3,300 tons of carbon stored on peatlands, half will be lost in the last 100 years due to the translation of peat to oil palm land. The amount of carbon lost is equivalent to the amount of carbon accumulated over 2,800 years.

Environmental problems such as those stated above cannot be taken lightly or even left alone. If environmental damage is not prevented and mitigated, then the loss will get worse and disturb the balance of the ecosystem. Unbalanced ecosystems can break the food chain (chain food) so that life in this biosphere will be disrupted. Plants as the primary producers will become extinct, followed by the death of herbivores, carnivores, and omnivores. Humans, as omnivorous creatures, threatened their lives.

All that can be prevented as long as humans have a strong desire to change for the better. It cannot be denied that the main factor causing ecological disasters is the human activity itself. Humans continue to exploit nature (overexploitation) without thinking about the consequences. Excessive exploitation of natural resources and human unfriendliness to the environment will be detrimental to humans themselves, especially for the younger generations to come. Human characters that tend not to be easily satisfied and selfish must immediately be changed into characters who care more about the environment.

It's not easy to change a person's character, because it takes time, habituating attitudes and behavior, and a relatively long process. However, with the right procedure and started as early as possible, it did not rule out the possibility to instill good character towards someone. One aspect that is urgent to be infused in the role of caring for the environment.

Cultivation of the character of environmental care can be done through education since children are still at an early age. The question is whether character education cares about the environment? What does this have to do with ecological disaster mitigation efforts? How do you teach character education about the environment from an early age? To find out the answers to these questions, the authors are compelled to make this scientific article with the title character education care for the environment early on as an effort to reduce the risk (mitigation) of ecological disasters.

\section{B. RESULT \& DISCUSSION}

\section{Basic Concepts of Character Education}

Character education is widely discussed, especially by academics in Indonesia, when the government makes character building one of the national development priority programs. In the

National Long-Term Development Plan (RPJPN) for 2005-2025, character education is placed as 
a foundation for realizing the vision of national development, namely realizing a humane, moral, ethical, cultured, and civilized society based on the Pancasila philosophy.

Education is one of the basic strategies of national character development, which in its implementation can use a variety of policies, namely socialization (awareness), empowerment, civilization, and systematic cooperation. The process of character education is based on a psychological totality that includes all the potentials of individual human beings, including cognitive, affective, and psychomotor (Ministry of National Education, 2011: 9). Etymologically, the term character comes from the Greek "harassing." Ryan and Bohlin (Zuchdi, et al., 2012: 16) interpret harassing as "to engrave," which means to paint, carve, or scratch. In the Big Indonesian Dictionary, character means character, character, mental characteristics, and character or character that distinguishes one person from another.

In terminology, Thomas Lickona (Zuchdi, 2012: 16) suggests that character is "A reliable inner disposition to respond to situations in a morally good away." Darmiyati Zuhdi added that style is identical with morals so that characters are universal human behavioral values, both related to God, himself, fellow humans, and the environment, which are manifested in daily behavior. From this, the concept of character education emerged.

According to the Ministry of National Education (2012: 4-5), character education is an effort to instill character values to students which include knowledge, awareness or will, and actions to implement the values of goodness and virtue, to God Almighty, self, fellow, the environment, and nationality, in order to become moral human beings while character values are attitudes and behaviors that are based on norms and values that apply in society, which include spiritual aspects, personal / personality aspects, social aspects, and environmental aspects.

Character education is not just about teaching what is right and what is wrong. More than that, character education is an attempt to instill good habits (habituation) so that students can behave and act on the values that have become his personality. In other words, good character education must involve good knowledge (moral knowing), good feeling or loving good (moral feeling), and ethical behavior (righteous action) to form the embodiment of student behavior and life attitudes (Ministry of National Education, 2011: 6).

This is in line with the opinion of Thomas Lickona, who is considered a bearer of character education. Lickona stated that character education contains three main elements, namely knowing the good (knowing good), desiring the good (loving good), and doing the good (doing good). Character refers to a series of thoughts (cognitive), feelings (affective), and behaviors (behaviors) that have become habits (habits) (Zuchdi et al., 2012: 16-17).

Based on the definitions of these experts, the writer can conclude that environmental education character education is an effort to instill character values to students in the form of a caring attitude towards the environment to create a mindset and daily behavior that is environmentally friendly (sustainable living).

Efforts to Mitigate Ecological Disasters Through Character Education for Environmental Care Early According to the Indonesian Disaster Mitigation Education Center (P2MB), the University of Education (UPI), mitigation is a series of efforts to reduce disaster risks, both 
through physical development and awareness-raising and capacity building to face the threat of disaster. Disaster mitigation is an activity that acts as an action to reduce the impact of disasters, or efforts made to minimize victims when an emergency occurs, both fatalities and property.

Ecological disaster mitigation means efforts to prevent the occurrence of disasters / environmental damage as a system of mutual relations between biotic and abiotic elements. One initiative that can be done is through awareness of each individual from an early age. The most effective step is through education. In this case, which plays an important role is the Early Childhood Education Institution (PAUD). PAUD, as an early childhood education institution, is considered appropriate to instill and foster the character of caring for the environment from old age.

The character of caring for the environment cannot be obtained instantly but requires a long process and a relatively long time. Someone will have a caring attitude towards the environment because of the habituation that takes place continuously and continuously. Habituations that take place consistently will be firmly planted in the subconscious mind so that they will later be exposed to their actions in daily life (habits) as the character values they have.

A child who has the character of caring for the environment will have a positive impact on the survival of the surrounding environment. The character cares about the situation that has been embedded from an early age will not fade quickly when he grows up. Even with the right education, the character will grow stronger. He will undoubtedly care more about the existence of animals, plants, water, soil, and the air around him as an interconnected ecosystem and must be protected. Thus, the ecosystem will be well preserved so that it is not easily damaged and cause ecological disasters everywhere. This is where the importance of efforts to prevent (mitigate) environmental disaster early on.

Character education care for the environment from an early age can be done in various ways, one of which is through the planting of conservation values. Conservation is an effort to manage and protect natural resources from remaining balanced and avoiding damage. Research conducted by Wakhidah (2014: 45) states that through the inculcation of conservation values has a significant influence on the development of environmental care characters for children aged 56 years. The research also shows that instilling conservation values by making habituation in daily learning activities by way of direct practice and exemplified by the teacher and all school members is a necessity so that children can preserve and care for the environment around them. Early Childhood Character Education Implementation

The implementation of environmentally friendly character education from old age can be done formally at the Early Childhood Education Institution (PAUD). This is based on character values that need to be introduced to early childhood following guidelines from the Ministry of National Education (Kemdiknas). Character values that are very important to be added and internalized into character education in early childhood include fifteen costs, namely: 1) Love of God; 2) Honesty; 3) Discipline; 4) Tolerance and love for peace; 5) Confidence; 6) Independent; 7) Please help, cooperation, and cooperation; 8) Respect and manners; 9) Responsibility; 10) Hard work; 11) Leadership and justice; 12) Creative; 13) Be humble; 14) Care for the environment; and 15) Love the nation and the motherland (Ministry of National Education, 2012: 5). 
Character education is an education that involves the cultivation of knowledge, love, and the inculcation of ethical behavior that becomes a pattern/habit. The values of character education that can be instilled in early childhood (0-6 years) include four aspects, namely: (1) Spiritual Aspects, (2) Personal/personality Aspects, (3) Social Aspects, and (4) Aspects environment (Ministry of National Education, 2012: 5).

The implementation of character education in early childhood has certain principles that need to be considered by educators and PAUD institutions. There are seven principles that must be implemented, namely: 1) Through example and example; 2) Performed in a sustainable manner; 3) Comprehensive, integrated in all aspects of development; 4) Creating an atmosphere of affection; 5) Actively motivating children; 6) Involving educators and education personnel, parents, and the community, and 7) Assessing.

According to the Ministry of National Education (2012: 7-11), inculcation of character values is given by example, habituation, and repetition in daily life. A safe and comfortable atmosphere and environment need to be created in the process of instilling character values. Instilling character values in children is not just hoping for obedience, but must be recognized and believed by children so that they feel that the benefits are indeed valid and beneficial for themselves and their environment. Thus they are motivated from within to implement and continue to maintain these values in their daily lives.

Referring to the Guidelines for Character Education in Early Childhood, the application of environmentally friendly character education for young children can be made through three stages, namely planning, implementation, and assessment which will be described as follows :

Planning Phase

Environmental education character planning is developed by taking into account the following matters.

1. It is knowing and understanding the child in full per the stages of development and its characteristics, such as children as accomplished researchers, actively moving, unyielding, open, and friendly.

2. The values of character education are applied together with the core learning activities carried out by:

a. Choose character values that fit the theme and title of the learning activity. In this case, the character value that is instilled is caring about the environment. The subject and title of the event are also related to environmental awareness.

b. Determine indicators of the development of character values, according to the stage of child development.

c. Determine the types and stages of activities to be carried out.

Implementation Stage

The implementation of environmental care character values for young children is carried out through programmed and habituated activities.

1. Programmed activities, for example: 
a. Explores the child's understanding of the values of the character cares about the environment. This activity can be done through storytelling and dialogue guided by the teacher. For example, for the theme "my environment," the teacher can ask open-ended questions about the characters responsible for protecting the environment. Examples of teacher questions, "Why should we be responsible for maintaining environmental cleanliness?" Or "How are we responsible for maintaining environmental hygiene?" Each child can give a different answer. All children's opinions are valued because they reflect their understanding.

b. Build the child's appreciation by involving his emotions to realize the importance of applying the values of environmental care characters. This process is also built through open-ended questions or through observing the ecological conditions and conditions surrounding the institution. For example, after telling stories and having dialogues about caring for the environment, teachers can take children around the institution to explore the surrounding environment. Then the teacher asks the question, "Why is the river so dirty?"; What about the fish in the river if the river is dirty? And what must we do to make the river clean again? "

c. Invite children to do embedded character values jointly. For example, after the child explores and is encouraged to do the character cares about the environment, the teacher allows the child to carry out the style according to the wishes and abilities of the child. For example, they are throwing garbage in the trash that has been provided, not throwing it into the river.

d. Monitor the achievement of the stages of development of students. In this case, the child is asked to share their activities and feelings after carrying out the operation. Teachers can provide reinforcement and praise and a touch of affection for what is reflected by the child, for example by saying, "Thank you, it's responsible for throwing trash in its place, hopefully no more throwing the trash into the river, so that the river remains clean and has lots of fish."

2. Habituation activities can be done through a. Routine activities of PAUD institutions Everyday activities are activities carried out in PAUD continuously and consistently at all times. Examples of regular events to embed environmental care characters include watering plants in the morning before the lesson starts, cleaning the class of rubbish before the experience ends, and community service cleaning the environment every Friday.

a. Spontaneous activities

Spontaneous activities are activities carried out directly or spontaneously at the same time, usually done when the teacher is aware of the child's actions that are not good, so it needs to be corrected and giving appreciation (appreciation, praise) of the character values applied by the child. For example, when children are littering, the teacher reprimands him, and when children are littering, the teacher praises him.

b. Exemplary

Exemplary is an activity that can be imitated and used as a role model. In this case, the teacher shows consistent behavior in realizing character values that can be 
observed by children in daily activities both inside or outside the institution. For example, teachers dress neatly and cleanly, care for plants happily, dispose of trash in their place, and love animals with great affection.

c. Conditioning

Conditioning, namely the situation and condition of PAUD institutions as supporters of character education activities. For example, by maintaining clean toilets, providing trash bins, and neatness of educational play equipment to instill character values such as the responsibility of K4 (Cleanliness, Health, Neatness, and Safety).

d. The culture of PAUD institutions.

Includes an atmosphere of life in an institution that reflects an attitude of caring for the environment and carrying out productive, innovative, creative, effective, and enjoyable learning activities. Besides the two ways above, there are also other ways that teachers can do by involving parents through parenting activities, for example by telling parents about character values that are being instilled in PAUD, so that these values are also applied and familiarized in a family environment.

\section{Assessment}

The purpose of the evaluation is to determine the extent of changes in attitudes and behavior of children after participating in activities that are loaded with character values. Assessment activities can be carried out continuously so that changes in children's attitudes and behavior can be seen in their entirety. The Ministry of National Education (2012: 12-13) states that in evaluating the success of character education, there are several principles that teachers must pay attention to:

1. Thorough. Assessment includes aspects of the process and results of instilling character values that gradually describe changes in children's attitudes and behavior.

2. Continuity. The assessment is carried out in a planned, gradual, and continuous manner to obtain an overall picture of the results of the inculcation of character values.

3. Objective. By what is experienced or happens to children by taking into account the differences in the uniqueness of each individual.

4. Educate. Assessment results are used to foster and encourage children to improve their abilities or develop attitudes and behaviors following character values.

5. Meaningfulness. The assessment results are useful for educators, caregivers, parents, students, and other parties.

\section{CONCLUSION}

Massive ecosystem damage can disrupt the balance of the components of life so that it will cause more severe ecological disasters. Ecological disasters will threaten the survival of living things on this earth. The environmental catastrophe occurred mainly because of human activity that is not responsible and does not have a sense of care for the environment. Ecological disasters must be prevented as soon as possible before they get worse. 
One effort to prevent (mitigation) against ecological disasters is through character education, especially character care for the environment. This environmental character education cannot be done instantly because the results will not be maximal. The implementation of ecological education character is more appropriate to be done as early as possible. This means that since early childhood has been taught the values of the characters care about the environment. The inculcation of these character values can be done through family education or institutions, both formal and informal. A child who in his soul already has a strong character of caring for the environment, even to adulthood, will still have a caring attitude towards the environment. Thus a person will not take actions that damage nature so that ecological disasters globally can be prevented before they occur. Potential intelligence and the basics of a child's behavior are formed in the range of early childhood. Therefore the authors propose several suggestions as follows:

1. It is better for parents and old childhood education institutions to instill ethical character values actively, for example, characters who care about the environment.

2. Need to do more comprehensive research related to character education about the environment for children from an early age.

3. Character education about the environment should be carried out continuously at every level of education. 


\section{References}

BNPB. 2016. Indonesian Disaster Data and Information, National Disaster Management Agency (BNPB), Accessed July 30, 2016, from http://dibi.bnpb.go.id

Jambeck, Jenna R., et al., 2015. Plastic Waste Inputs from Land into the Ocean. Sciencemag Vol. 345 Issue 6223

Ministry of National Education. 2011. Guidelines for Implementing Character Education. Jakarta: Curriculum Center and Bookkeeping Ministry of National Education

Ministry of National Education. 2012. Guidelines for Character Education in Early Childhood Education. Jakarta: Director General of PAUD Ministry of National Education

Kristi, Elin Yunita. 2010. Indonesia, Ranks Four Environmental Destruction. Accessed March 7, 2016, from http://nasional.news.viva.co.id/news/read/149597-indonesia-rangking-empatperusak-lunganungan

Moss, Catriona. 2015. Peatland loss could emit 2,800 years' worth of carbon in an evolutionary eyeblink: study. Accessed March 7, 2016, from http://blog.cifor.org/26254/indonesiapeatland-forest-carbon-emissions-

model\#.VTd5gZMnJp4?utm_source=RD\&utm_medium=inart\&utm_campa ign = khiprdrd

Nasution, Arifsyah., Et.al. 2016. Greenpeace Calls for Indonesia to be Waste-Free and Incinerator Free. Accessed March 7, from http://www.greenpeace.org/seasia/id/press/Greenpeace-Claim-Indonesia-Bebas-Sampahdan-Bebas-Insinerator---/

Pramesti, Olivia Lewi. 2012. Portrait of Indonesia's Environment Increasingly Concerned. Accessed http://nationalgeographic.co.id/berita/2012/10/potret-lingkungan-indonesiakian-m worrying about

Center for Disaster Mitigation Education (P2MB). 2010. Mitigation. Assessed on March 7, 2016, from http://p2mb.geografi.upi.edu/Mitigasi_Bencana.html

Sumargo, Wirendro., Et.al. 2011. Portrait of the State of Indonesia's Forests for the Period of 20002009. Jakarta: Forest Watch Indonesia

Utomo, Yunanto Wiji. 2015. Earth Day and Sad Facts about Indonesian Nature. Accessed http://sains.kompas.com/read/2015/04/22/20042431/Hari.Bumi.dan.Faktafakta.Medic.about.Alam.Indonesia

Wakhidah, Kholidatul. 2014. The Effect of Planting Conservation Values on Caring Characters in Early Childhood Environments. Journal of Early Childhood Education Papers / BELIA 3 (2) (2014)

Walhi. 2015. Environmental Review 2015, Collecting Promises to Demand Change. Jakarta: Indonesian Forum for the Environment

WWF Indonesia. 2009. Environmental Damage amid Climate Change Threats. Accessed March 7, 2016, from http://www.wwf.or.id/?4243/Damage-Lingkungan-di-tengah-Ancaman-Per Change-Iklim 
International Journal of Science and Society, Volume 1, Issue 3, 2019

Zucchini, Darmiyati., Et.al. 2012. Character Education, Basic Concepts, and Implementation in Higher Education. Yogyakarta: UNY Press 